\title{
Assessing the Agronomical and Environmental Impacts of the Application of Green Waste-derived Compost on Sugar Beet Under Deficit Irrigation Conditions
}

Sami A. Al-Dhumri

Taif University

Amr M. El-darder

Nobaria Sugar and Refining Company

Mohammed A. Alfurayji

Qassim University College of Agriculture and Veterinary Medicine

Salah Fatouh Abou-Elwafa ( $\sim$ elwafa75@aun.edu.eg)

Assiut University Faculty of Agriculture https://orcid.org/0000-0002-9018-598X

\section{Research Article}

Keywords: Sugar beet, Compost, Drip irrigation, Sprinkler irrigation, Drought

Posted Date: November 10th, 2021

DOI: https://doi.org/10.21203/rs.3.rs-1061371/v1

License: (c) (1) This work is licensed under a Creative Commons Attribution 4.0 International License.

Read Full License 

derived compost on sugar beet under deficit irrigation conditions

3 Sami A. Al-Dhumri ${ }^{1}$, Amr M. El-darder ${ }^{2}$, Mohammed A. Alfurayji ${ }^{3}$, Salah Fatouh Abou-Elwafa ${ }^{4}$

$4 \quad{ }^{1}$ Department of Biology, Alkhurma University College, Taif University, P.O. Box 11099, Taif 21944, Saudi Arabia.

$5 \quad{ }^{2}$ Nobaria Sugar Industry and Refining Company, El-Beheira, Egypt.

$6{ }^{3}$ Department of Plant Production and Protection, College of Agriculture and Vet.Med., Qassim University, Saudi $7 \quad$ Arabia.

$8 \quad{ }^{4}$ Agronomy Department, Faculty of Agriculture, Assiut University, 71526 Assiut, Egypt.

9

10 Corresponding author:

11 Salah F. Abou-Elwafa

12 Agronomy Department, Faculty of Agriculture, Assiut University, 71526 Assiut, Egypt.

13 E-Mail: elwafa75@aun.edu.eg

14

15

16 

derived compost on sugar beet under deficit irrigation conditions

Abstract

In the light of global warming and climate changes, as well as the rapid expansion in sugar beet

21 production in the arid and semi-arid regions, improving sugar beet productivity under deficit

22 irrigation is of great importance. Green waste-derived compost (GWC) is a valuable soil

23 amendment for improving soil organic matter, decreasing waste products and potential pollutants.

24 The application of 14 ton $\mathrm{ha}^{-1}$ of GWC resulted in the highest root and recoverable sugar yields 25 especially under the well-irrigated conditions under drip irrigation. Although, the impurities\% in the beet root juice was increased under deficit irrigation conditions, sugar beet root biofortification

27 and juice quality were significantly improved under drip irrigation in response to the application of 14 ton $\mathrm{ha}^{-1}$ of GWC by increasing sucrose content, QZ\% and RS\%. The application of GWC under drip irrigation enhanced water use efficiency for root yield (WUERY) and recoverable sugar yield (WUE $E_{R S Y}$ ), in particular under drip irrigation. The soil chemical and physical properties were

31 significantly improved in response to the application of GWC. The results indicate that the 32 application of GWC is essential for the sustainable sugar beet production and efficient irrigation 33 water use in sandy soils.

34 Keywords: Sugar beet; Compost; Drip irrigation; Sprinkler irrigation; Drought 


\section{Introduction}

37 Production of sugar beet (Beta vulgaris, L.) in the arid and semi-arid regions to replace or supplement cane sugar production (Abou-Elwafa et al. 2020; Alotaibi et al. 2021). The main advantages of sugar beet cultivation as a promising sugar crop in these areas is its ability to effectively grow and produce a high sugar content and yield in a short growing period. Besides, in addition to its ability to efficiently grow in the newly reclaimed soils which are comment in these areas, sugar beet has a lower irrigation requirement (Abo-Elwafa et al. 2013; Abou-Elwafa et al. 2020; Balakrishnan and Selvakumar 2009).

Drought stress is the most devastated abiotic stress that cause great crop losses worldwide. In the light of global warming and climate changes, where some geographical regions are expected to face frequent severe drought conditions, the development of agronomical practices to improve crop productivity by enabling plants to cope with deficit irrigation conditions is considered as efficient and cost-effective strategy to overcome drought stress in low-value cropping systems (Abou-Elwafa 2016; Abou-Elwafa and Shehzad 2021; Simova-Stoilova et al. 2016). Therefore, significant efforts have been carried out to minimize the impacts of drought stress on the potential yield and quality of sugar beet (Abou-Elwafa et al. 2020). The occurrence of drought stress early in the growing season exhibits adverse effects on root growth and development of sugar beet. Meanwhile, when drought stress occurred during the late growth stages, the leaf area and number of leaves, and thereby the photosynthetic capacity would be reduced. Furthermore, drought could adversely affect soil microorganisms leading to enhancing the susceptibility of crop plants to drought stress. Microorganisms could promote plant resistance to drought stress through several independent mechanisms, e.g., producing) the production of polysaccharides that enhances soil structure and water-holding capacity, ii) the production of indoleacetic acid (IAA), deaminase and proline that induce drought tolerance in crop plants, iii) enhancing water circulation trough fungal mycelia, and iv) adverse impacts on microbial community structure and abundance, and thereby reducing nutrient availability (Milošević et al. 2012; Nguyen et al. 2018). Furthermore, drought

62 stress would increase the concentrations of $\mathrm{Na}, \mathrm{K}$ and $\alpha$-amino-N, which adversely affect sugar recovery from the roots (Putnik-Delić et al. 2013).

64 Green waste-derived compost (GWC) is a concept for waste recycling and utilization that has been 65 recently become an essential approach for relieving urban green waste and improving urban 
polluted soil (Bai et al. 2010; Jones et al. 2009; Vargas-Hernández et al. 2018). The reduction in

67 the soil organic matter due to intensive cropping systems, and the increase in the water pollution caused by the elevated concentration of animal production has made the application of green waste-derived compost (GWC) a valuable approach for improving the soil organic matter while decreasing waste products and potential pollutants (Peigné and Girardin 2004). GWC is known to has a high water-holding capacity and can supply water to plants over time, and thereby increases the water retention of GWC amended soils (Kranz et al. 2020). The application of GWC increases water availability to the plants and relieves the suppressant effect of irrigation deficit on plant productivity (Nguyen et al. 2012).

Environmentally, a major advantage of the application of GWC for soil amendment and improvement beside its higher organic matter content is that it is a low pollutant and costs (Aziablé and Kolédzi 2018; Sánchez-Monedero et al. 2019). Furthermore, when mixed with the soil, GWC releases a large number of microorganisms into the soil and hence increases the soil microbes. These microbes would have a significant impact on the decomposition of organic matter, and the accumulation and bioavailability of soil nutrients leading to an increase in the agricultural productivity to ensure food security to a great extent (Ayilara et al. 2020; Tong et al. 2018). Additionally, the application of GWC in the field has been proven to reduce nitrogen losses, which is essential for sustainable agriculture (Ullah et al. 2020). Moreover, GWC application helps in protecting the underground water from becoming polluted.

The present study aims to i) evaluate the impact of green waste-derived compost (GWC) application on yield and quality of sugar beet under different irrigation systems in sandy soils, and ii) evaluate the effect of GWC application on water-use efficiency and drought tolerance of sugar beet in sandy soils.

\section{Materials and Methods}

\section{Plant materials and experiments}

A field experiment was conducted at the Nobaria Sugar Industry and Refining Company, ElBeheira, Egypt (L 30,38 4" N, 30o, 13.35, 9" E 28 m asl) during the 2017/2018 and 2018/2019 growing seasons. A commercial sugar beet variety designated Gazelle was used in both growing seasons. Seeds were sown on September 23 and 27 and plants were harvested on April 10 and 13, in the first and second growing seasons, respectively. Seeds were hand sown at $15 \mathrm{~cm}$ spaces in a 
$15 \mathrm{~m}^{2}$ plot consists of 5 rows of $5 \mathrm{~m}$ in length, with $60 \mathrm{~cm}$ between rows. the green waste-derived compost (GWC) was applied as a soil amendment in two doses, i.e., 0 and $14 \mathrm{tha}^{-1}$. The chemical analysis of the applied GWC is shown in Suppl. Table 1. Three levels of 60, 80 and 100\% of the soil field capacity of either drip and sprinkler irrigation systems were applied. The application of $\mathrm{N}, \mathrm{P}$ and $\mathrm{K}$ and other cultural practices were carried out according to the locally recommended practices for sugar beet production. In brief, super phosphate $\left(15.5 \% \mathrm{P}_{2} \mathrm{O}_{5}\right)$ was applied during soil bed preparation at a rate of $475 \mathrm{~kg} \mathrm{ha}^{-1}$. Nitrogen was applied at a rate of $250 \mathrm{~kg} \mathrm{ha}^{-1}$ in the form of urea $(46.5 \% \mathrm{~N})$ in two equal doses, i.e., the first one after thinning (4-6 leaves-old plant), and the second one applied 4 weeks later. Potassium sulphate $\left(50 \% \mathrm{~K}_{2} \mathrm{O}\right)$ was applied 4 weeks after sowing at a rate of $120 \mathrm{~kg} \mathrm{ha}^{-1}$.

A tri-replicate split-split plot design arranged in a randomized complete block design (RCBD) was used. The main plots were assigned to the two applied irrigation systems, i.e., drip and sprinkler irrigation. The deficit irrigation treatments allocated to the sup-plot, whereas the sub-sub-plots were assigned to the application of GWC as a soil amendment.

\section{Characterization of experimental soil and irrigation water}

Composite representative samples were collected from the surface layer $(0-30 \mathrm{~cm})$ of the experimental soil for analyzing the physical and chemical properties before sowing. After harvest, soil samples were collected from each plot and chemically analyzed. After air-drying, soil samples were ground and sieved using $2 \mathrm{~mm}$ sieves. The soil $\mathrm{pH}$ was estimated in a 1:2.5 of soil to deionized water suspension using a glass electrode (Jackson 1973). A 1:2.5 of soil to water extract was implemented to measure the soil electrical conductivity (EC) using the EC meter (Hesse 1998). Available nitrogen in the soil was extracted using $2 \mathrm{M}$ potassium chloride and microkjeldahl method was employed to was determined then nitrogen in the extract (Burt 2004). A 0.5 $\mathrm{M}$ sodium bicarbonate solution was used to extract the available soil phosphorus at $\mathrm{pH} 8.5$ and then the spectrophotometer set at a wavelength of. $400 \mathrm{~m} \mu$ was employed to measure phosphorus (Olsen 1954). Extraction of the available soil potassium was performed according to the ammonium acetate procedure at $\mathrm{pH}$ 7.0. Potassium was then measured using flame photometry (Jackson 1973). Estimation of the organic matter (OM) in the soil was performed using the Walkley-Black method (Jackson 1973). The main physical and chemical soil properties are shown in Suppl. Table 2. 
Irrigation water used in the experiment was pumped from a well. The chemical analysis of the irrigation water was performed according to the (AOAC 1970) (Suppl. Table 3). Irrigation was performed by drip and sprinkler irrigation systems. The distance between the drippers was $20 \mathrm{~cm}$. Sprinkler irrigation was applied with $4 \mathrm{~m}$ and $5 \mathrm{~m}$ sprinkler spacing. Irrigation was applied based on measuring the soil field capacity using the undisturbed method essentially described by (Ali 2010). Well-irrigated treatment was irrigated when the soil moisture reached $40 \%$ of the field capacity, meanwhile the drought-stressed treatments were irrigated when the soil moisture reached 24 and $30 \%$ of the soil field capacity (60 and $75 \%$ of the well-irrigated treatment).

\section{Phenotypic evaluation}

At harvest, roots from the three guarded rows of each plot were employed to determine root yield, and a representative root sample was used for analysis of juice quality at the Nobaria Sugar Industry and Refining Company laboratory. Sucrose $\%, \mathrm{Na} \%, \mathrm{~K} \%, \alpha$-amino- $\mathrm{N}$ and quality index (QZ) were measured. Impurities and recoverable sugar (RS)\% were calculated according to (Reinefield et al. 1974) as follow:

$$
\text { Impurities } \%=[0.343(\mathrm{~K}+\mathrm{Na})+0.094 \alpha-\text { amino } \mathrm{N}+0.29]
$$$$
\text { Sugar recovery } \%=\text { Pol }-0.29-0.343(K+N a)-0.094(\alpha-\text { amino } N)
$$

Recoverable sugar yield (RSY) in tons per hectare was also estimated.

\section{Crop water use parameters}

Several water parameters were determined including:

i) Reference Evapotranspiration (ETo): was calaculated according to the Penman-Monteith method was used in CROPWAT model (Smith 1992) using the available meteorological data from Wadi El-Natrun meteorological station (Suppl. Table 4) according to the following formula:

$$
\text { ETo }=\frac{0.408 \Delta\left(R_{n}-G\right)+\gamma \frac{900}{T+273} u_{2}\left(e_{s}-e_{a}\right)}{\Delta+\gamma\left(1+0.34 u_{2}\right)}
$$

where $E T \mathrm{O}=$ reference evapotranspiration rate $\left(\mathrm{mm} \mathrm{d}^{-1}\right), T=$ average air temperature $\left({ }^{\circ} \mathrm{C}\right)$, and $\mathrm{u}_{2}$ $=$ wind speed $\left(\mathrm{m} \mathrm{s}^{-1}\right)$ at $2 \mathrm{~m}$ above soil surface, $R_{n}=$ net radiation $\left(M^{-2} \mathrm{~m}^{-1}\right) \mathrm{G}=$ soil heat flux 
$152\left(\mathrm{MJ} \mathrm{m}^{-2} \mathrm{~d}^{-1}\right), \Delta=$ slope of vapor pressure and temperature curve $\left(\mathrm{kPa}^{\circ} \mathrm{C}^{-1}\right), \gamma=$ psychrometric 153 constant $\left(\mathrm{kPa}^{\circ} \mathrm{C}^{-1}\right)$, and es - ea= vapor pressure deficit $(\mathrm{kPa})$.

154 ii) The amount of irrigation water was calculated using the following equation (Vermeirn and 155 Gopling 1984):

$$
A I W=\frac{\text { ETo } \times \mathrm{KcI}}{E a(1-L R)}
$$

157 where: $\mathrm{ETo}=$ Reference evapotranspiration, $\mathrm{Kc}=$ crop coefficient (for sugar beet crop as reported 158 by FAO, Allen et al. 1998), I= irrigation intervals (days), Ea= irrigation efficiency of the drip and 159 sprinkler irrigation systems, and LR = leaching requirements.

160 The irrigation time for drip irrigation system was estimated in advance by measuring the actual 161 emitter discharges according to the following equation:

$$
t=\frac{A I W \times \mathrm{A}}{q}(\text { Ismail 2002) }
$$

163 where $\mathrm{t}=$ irrigation time $(\mathrm{h}), \mathrm{A}=$ wetted area $\left(\mathrm{cm}^{2}\right)$, and $\mathrm{q}=$ emitter discharge $\left(\mathrm{L} \mathrm{h}^{-1}\right)$.

164 The irrigation time for sprinkler irrigation system was estimated according to the following 165 equation:

$$
t=\frac{A I W}{A R}(\text { Holzapfel et al. 2009) }
$$

167 where $\mathrm{AR}=$ application rate $\left(\mathrm{mm} \mathrm{h}^{-1}\right)$

$$
A R=\frac{1000 \times \mathrm{Q}}{L_{l} \times L_{S}}(\text { Holzapfel et al. 2009) }
$$

169 where $\mathrm{Q}=$ sprinkler discharge $\left(\mathrm{m}^{3} \mathrm{~h}^{-1}\right), \mathrm{L}_{\mathrm{l}}=$ distance between lateral $(\mathrm{m}) \mathrm{L}_{\mathrm{s}}=$ distance between 170 sprinkler $(\mathrm{m})$.

171 iii) Water use efficiency (WUE) was calculated using the following formula according to (Jensen 172 1980):

$$
W U E=\frac{\text { Crop yield }\left(\mathrm{kg} \mathrm{ha}^{-1}\right)}{\text { Applied irrigation water }\left(\mathrm{m}^{3} \mathrm{ha}^{-1}\right)}
$$

\section{Statistical analysis}

175 The Proc Mixed model in the SAS 130 package version 9.2 was implemented to carry out the 
analysis of variance (ANOVA) and Fisher's least significant difference (LSD) of significantly differed treatments. The linear regression analysis was performed using the SigmaPlot 14 Software (Systat Software, San Jose, CA, USA).

\section{Results}

\section{Effect of GWC application and irrigation systems on beet yields under deficit irrigation conditions}

The application of the green waste-derived compost (GWC), irrigation systems and deficit irrigation conditions exhibited highly significant effects on water use efficiency (WUE), root and recoverable sugar yields (Table 1). The highest root and recoverable sugar yields $(56.50,9.81$ and 55.77, 9.17 ton $\mathrm{ha}^{-1}$, in the first and second growing seasons, respectively) resulted from the application of 14 ton $\mathrm{ha}^{-1}$ of GWC in the two growing seasons (Table 1). Deficit irrigation significantly reduced both root and sugar yields, and the highest values were produced from the $100 \%$ irrigation treatment in both growing seasons (Table 1). Moreover, the employment of drip irrigation has significantly improved root and recoverable sugar yields in both growing seasons (Table 1).

The interactions between GWC application, irrigation systems and deficit irrigation treatments exhibited significant and highly significant effects on root and recoverable sugar yields (Table 1). The application of GWC at the rate of 14 ton $\mathrm{ha}^{-1}$ under drip irrigation exhibited the highest root and recoverable sugar yields under the $100 \%$ irrigation treatment in both growing seasons (Table 1).

\section{Effect of GWC application and irrigation systems on beet root juice quality under deficit irrigation conditions}

The application of GWC exhibited significant effects on beet root juice quality parameters, i.e., sucrose content, quality index (QZ\%), recoverable sugar (RS)\% and impurities\% in the two growing seasons. The application of 14 ton $\mathrm{ha}^{-1}$ of GWC significantly improved beet root biofortification and juice quality by increasing sucrose content, QZ\% and RS\%. However, the impurities\% in the beet root juice was significantly increased in response to the application of GWC in both growing seasons (Table 2). Irrigation systems significantly affect sucrose content, QZ, RS and impurities in the two growing seasons. The QZ and RS were significantly increased 
under drip irrigation system, whereas the impurities were reduced in response to the employment of drip irrigation (Table 2). All quality parameters including, sucrose, QZ, RS and impurities differed significantly in response to deficit irrigation in the two growing seasons. The juice quality and impurity parameters, i.e., sucrose $\%, \mathrm{RS} \%, \mathrm{QZ} \%$ and impurities, were increased in the beet root juice in response to deficit irrigation leading to an overall considerable improvement in the juice quality and root biofortification.

The interaction between GWC application, irrigation systems and water deficit treatments revealed significant effects on all measured quality traits in both growing seasons (Table 2). The highest values of sucrose, QZ and RS (20.76 and 20.51\%, 87.20 and 86.60\%, and 17.99 and $16.97 \%$, in the first and second growing seasons, respectively) resulted from the application of 14 ton ha ${ }^{-1}$ of GWC under drip irrigation conditions in combination with the $60 \%$ irrigation deficit treatment (Table 2). Meanwhile, the lowest impurity values (2.30 and 2.43, in the first and second growing seasons, respectively) resulted from the employment of sprinkler irrigation without GWC application under the well-irrigated treatment (100\% irrigation treatment).

\section{Effect of GWC application and irrigation systems on WUE under deficit irrigation conditions}

Water use efficiency calculated for either root yield (WUERY) or recoverable sugar yield (WUERSY) were significantly influenced by the application of the green waste-derived compost (GWC), irrigation systems and deficit irrigation conditions (Table 3). The highest WUERY and WUERSY values resulted from the application of 14 ton $\mathrm{ha}^{-1}$ of GWC in the two growing seasons (Table 3). WUE was significantly promoted in response to deficit irrigation, and the highest $W_{R Y}$ and WUERS values were produced under the $60 \%$ deficit irrigation treatment in both growing seasons (Table 3). Furthermore, the employment of drip irrigation has significantly enhanced both WUERY and WUERSY in both growing seasons (Table 3).

WUERY and WUERSY were significantly affected bey the interactions between GWC application, irrigation systems and deficit irrigation treatments in both growing seasons (Table 3). The highest WUERY and WUERSY values (12.72 and 2.27, and 12.91 and 2.18, in the first and second growing seasons, respectively) resulted from the application of 14 ton $\mathrm{ha}^{-1}$ of GWC under drip irrigation conditions in combination with the $60 \%$ deficit irrigation treatment (Table 3).

\section{Effect of GWC application on soil chemical properties}


235 The application of GWC significantly increased the available N, P and K in the soil. Similarly,

236 GWC application significantly influenced the contents of calcium $\left(\mathrm{Ca}^{2+}\right)$, magnesium $\left(\mathrm{Mg}^{+}\right)$,

237 sodium $\left(\mathrm{Na}^{+}\right)$, potassium $\left(\mathrm{K}^{+}\right)$, chlorine $\left(\mathrm{Cl}^{-}\right)$, bicarbonate $\left(\mathrm{HCO}_{3}{ }^{2-}\right)$ and sulfate $\left(\mathrm{SO}_{4}^{-}\right)$ions

238 compared to the control treatment (Table 5).

239 The interaction between GWC application, irrigation systems and water deficit treatments

240 exhibited significant effects on soluble cations, anions and some macronutrients in the soil after

241 sugar beet harvest (Table 1). The highest values of all soluble cations and anions in the soil after

242 sugar beet harvest were obtained from the application of GWC under drip irrigation conditions in

243 combination with the 60\% irrigation deficit treatment (Table 4).

\section{Correlation and regression analyses between GWC application and root quality}

245 parameters

246 Root yields revealed positive highly significant positive correlations with the recoverable sugar

247 yields (RSY). Moreover, sucrose content exhibited highly significant positive correlations with

248 the quality index and the recoverable sugar percentage (RS\%). Meanwhile, the correlation

249 between impurity\% and quality index (QZ) was highly significant negative (Table 5). Linear

250 regression analysis between the recoverable impurities\% and either RS\% and RSY revealed

251 negative under either the control treatment or the application of GWC across the two growing

252 seasons fitted to the linear equation. The general linear model regression exhibited negative correlations

253 between impurities\% and either RS\% or RSY, with a coefficient of determination $\left(\mathrm{R}^{2}\right)$ ranged

254 from 0.301-0.836 (Figure 1). However, these negative correlations were more sharp and strong

255 under GWC application as indicated by the $\mathrm{R}^{2}$ values (Figure 1).

256 Discussion

257 In the light of climate changes, global warming, steady population growth, diminishing sugarcane

258 cultivated area and irrigation shortage, promoting sugar beet cultivation in arid and semi-arid 259 regions is the only possible solution to overcome the gap between sugar production and 260 consumption in Egypt (Abo-Elwafa et al. 2006; Aljabri et al. 2021). This necessitates to seek the 261 application of agronomical practices that would improve sugar beet productivity to cope with 262 deficit irrigation conditions. The current study was conducted to evaluate the impact of the 263 application of green waste-derived compost (GWC) on the performance and yielding ability of 264 sugar beet under irrigation deficit conditions. 
In the present study, the application of GWC significantly increased sugar content and $\mathrm{RS} \%$ as well as impurity\% which in turn reduced the root juice quality index (QZ). The higher sucrose contents observed in response to the GWC application could be attributed to the elevated plant growth caused by GWC application which led to an increase in the photosynthetic capacities of the plants and the accumulation of more sucrose in the roots (Anli et al. 2020; Pedroza-Sandoval et al. 2017; Rady et al. 2016). Besides, it has been reported that GWC could accelerate the synthesis of photosynthetic pigments not only by supplying essential nutrients but also by changing the physical and chemical properties of the growth media, and hence reducing nutrients leaching and increasing plants water-use efficiency (Elhindi 2012). Meanwhile, the reduction in the $\mathrm{RS} \%$ as a result of the application of GWC could be attributed to the increase in the impurity levels. The increased impurity and the reduced QZ levels in response to the application of GWC might be due to that the improved metal solubility, mobility and bioavailability in the soils which in the presence of low $\mathrm{Ca}^{2+}$ content promotes the absorption of $\mathrm{Na}^{+}, \mathrm{K}^{+}$and $\alpha$-amino nitrogen and therefore affected membrane permeability to control sodium absorption (Wakeel 2013). This is obvious from the strong negative linear regressions between impurities percentage in the root juice and the recoverable sugar percentage and recoverable sugar yield observed under the application of GWC (Figure 1) support this hypothesis. Besides, soil amendment materials would exhibit contradictory impacts on the mobilization and phytoavailability of elements depending on the type of the applied soil amendment and the element (Shaheen et al. 2017). The application of GWC promoted root yield in both growing seasons, which might be due to that GWC dramatically improves the soil physical and chemical properties and enhances the nutrients solubility and phytoavailablity in the soil and thereby promotes sugar beet growth and yield (Businelli et al. 2009; Smolinska 2015). The significant increase in the recoverable sugar yield resulted from the application of GWC is likely due to the high root yields produced from the application.

The significant improvement in the sugar beet water-use efficiency calculated for either root yield $\left(W_{U} E_{R Y}\right)$ or recoverable sugar yield $\left(W_{U E S}\right)$ in response to the application of GWC, in particular under irrigation deficit conditions suggest that GWC application has enhanced the water-holding capacity of the soil, and thereby promoted the ability of the plants to face irrigation deficit and to use the applied water more efficiently. The soil water-holding capacity is the most determinant factor for water-use efficiency (WUE) in agriculture. The application of 
296 GWC is a powerful approach to improve soil organic matter, which has been evidently proven to 297 be the key responsible factor for water-holding capacity (Martínez-Blanco et al. 2013; Sayara et al. 2020). In large granules soil such as sandy soils, compost serves as a sponge that holds water, therefore, application of compost to sandy soils is considered an ideal promising natural fertilizing approach to overcome the adverse consequences of climate change and water shortage, in particular in arid and semi-arid regions (Adugna 2016; Garcia et al. 2017; Skuras and Psaltopoulos 2012). The drastically elevated contents of soluble cations, anions and some macronutrients in the soil after harvest in response to the application of GWC is consistent with the role of compost application in the soil in increasing metal availability by the formation of soluble metal-organic complexes, and hence increasing the plant uptake efficiency (Businelli et al. 2009; Rady et al. 2016; Smolinska 2015; Zheljazkov and Warman 2004).

In conclusion, the current study root yield was increased in response to the application of green waste-derived compost (GWC), which could be ascribed to the great improvement in the physical and chemical properties of the soil, and nutrients mobilization and uptake. The improved metal solubility, mobility and bioavailability in the soil caused by the application of GWC further enhanced sugar content, RS\% and impurity\%, however, the root juice quality index (QZ) was reduced. The improved water-holding capacity of the soil in response to the application of GWC has increased water-use efficiency, in particular under irrigation deficit conditions.

\section{Ethics approval and consent to participate}

316 Not applicable.

\section{Consent to Participate}

318 Not applicable.

\section{Funding}

320 Not applicable.

\section{Authors' contributions}

322 SFA conceived the study, analyzed the data, and wrote the manuscript. FMI performed the 323 experiment and collected the data. MA, SA, RNA and JC helped in data analysis and 324 presentation. All authors read and approved the final version of the manuscript. 


\section{Availability of data and material}

326 All data are included within the manuscript and its supplementary material.

\section{Competing interests}

328 The authors declare that there is no conflict of interest.

\section{Acknowledgments}

The authors are thankful to Taif University Research Supporting Project number (TURSP2020/315), Taif University, Taif, Saudi Arabia, for providing the financial support and research facilities.

\section{References}

Abo-Elwafa SF, Abdel-Rahim HM, Abou-Salama AM, Teama E-MA (2013) Effect of Root Age and Day-Length Extension on Sugar Beet Floral Induction and Fertility. World Journal of Agricultural Research 1

Abo-Elwafa SF, Abdel-Rahim HM, Abou-Salama AM, Teama EA (2006) Sugar beet floral induction and fertility: effect of vernalization and day-length extension. Sugar Tech 8:281-287

Abou-Elwafa SF (2016) Association mapping for drought tolerance in barley at the reproductive stage. Cr Biol 339:51-59

Abou-Elwafa SF, Amin AE-EA, Eujayl I (2020) Genetic diversity of sugar beet under heat stress and deficit irrigation. Agronomy Journal 112:3579-3590

Abou-Elwafa SF, Shehzad T (2021) Genetic diversity, GWAS and prediction for drought and terminal heat stress tolerance in bread wheat (Triticum aestivum L.). Genetic Resources and Crop Evolution 68:711-728

Adugna $G$ (2016) A review on impact of compost on soil properties, water use and crop productivity. Acad Res J Agric Sci Res 4:93-104

Ali MH (2010) Fundamentals of Irrigation and On-farm Water Management: Volume 1. Springer, Heidelberg

Aljabri M, Alharbi S, Al-Qthanin RN, Ismaeil FM, Chen J, Abou-Elwafa SF (2021) Recycling of beet sugar byproducts and wastes enhances sugar beet productivity and salt redistribution in saline soils. Environmental Science and Pollution Research

Alotaibi F, Bamagoos AA, Ismaeil FM, Zhang W, Abou-Elwafa SF (2021) Application of beet sugar byproducts improves sugar beet biofortification in saline soils and reduces sugar losses in beet sugar processing. Environmental Science and Pollution Research

Anli M, Baslam M, Tahiri A, Raklami A, Symanczik S, Boutasknit A, Ait-El-Mokhtar M, BenLaouane R, Toubali S, Ait Rahou Y, Ait Chitt M, Oufdou K, Mitsui T, Hafidi M, Meddich A (2020) Biofertilizers as Strategies to Improve Photosynthetic Apparatus, Growth, and Drought Stress Tolerance in the Date Palm. Frontiers in Plant Science 11 
AOAC (1970) Official Methods of Analysis, 11th edn. Association of Official Analytical Chemists, Washington, DC

Ayilara MS, Olanrewaju OS, Babalola OO, Odeyemi O (2020) Waste Management through Composting: Challenges and Potentials. Sustainability 12:4456

Aziablé E, Kolédzi EK (2018) Study of Agronomic and Environmental Profile of Compost and Fine Fraction Produced and Stored in a Shed at Composting Site: ENPRO Composting Site, Lomé, Togo. Science Journal of Chemistry 6:95-98

Bai J, Shen H, Dong S (2010) Study on eco-utilization and treatments of highway greening waste. Procedia Environmental Sciences 2:25-31

Balakrishnan A, Selvakumar T (2009) Evaluation of suitable tropical sugarbeet hybrids with optimum time of sowing. Sugar Tech 11:65-68

Burt R (2004) Soil survey laboratory methods manual. Soil Survey Investigations Report No. 42. In: $4.0 \mathrm{~V}$ (ed). United States Department of Agriculture, Natural Resources Conservation Service, National Soil Survey Center, USA

Businelli D, Massaccesi L, Said-Pullicino D, Gigliotti G (2009) Long-term distribution, mobility and plant availability of compost-derived heavy metals in a landfill covering soil. Science of The Total Environment 407:1426-1435

Elhindi KM (2012) Evaluation of composted green waste fertigation through surface and subsurface drip irrigation systems on pot marigold plants ('Calendula officinalis' L.) grown on sandy soil. Southern Cross Journals

Garcia C, Hernandez T, Coll MD, Ondoño S (2017) Organic amendments for soil restoration in arid and semiarid areas: a review. AIMS Environmental Science 4:640-676

Hesse PR (1998) A textbook of soil chemical analysis. CBS Publishers \& Distributors, Delhi, India Holzapfel EA, Pannunzio A, Lorite I, Oliveira ASSd, Farkas5 I (2009) Design and management of irrigation systems. Chilean Journal of Agricultural Research 69:17-25

Jackson ML (1973) Soil chemical analysis. In: Englewood Cliffs N (ed). Prentice-Hall, Inc., New Delhi, India

Jensen M (1980) Design and Operation of Farm Irrigation Systems.

Jones DL, Chesworth S, Khalid M, Iqbal Z (2009) Assessing the addition of mineral processing waste to green waste-derived compost: An agronomic, environmental and economic appraisal. Bioresource Technology 100:770-777

Kranz CN, McLaughlin RA, Johnson A, Miller G, Heitman JL (2020) The effects of compost incorporation on soil physical properties in urban soils - A concise review. Journal of Environmental Management 261:110209

Martínez-Blanco J, Lazcano C, Christensen TH, Muñoz P, Rieradevall J, Møller J, Antón A, Boldrin A (2013) Compost benefits for agriculture evaluated by life cycle assessment. A review. Agronomy for Sustainable Development 33:721-732

Milošević AN, Marinković BJ, Tintor BB (2012) Mitigating abiotic stress in crop plants by microorganisms. Proc Nat Sci Matica Serpska Novi Sad 123:17-26 
Nguyen LTT, Osanai Y, Anderson IC, Bange MP, Tissue DT, Singh BK (2018) Flooding and prolonged drought have differential legacy impacts on soil nitrogen cycling, microbial communities and plant productivity. Plant and Soil 431:371-387

Nguyen T, Fuentes S, Marschner P (2012) Effects of compost on water availability and gas exchange in tomato during drought and recovery. Plant Soil Environ 58:495-502

Olsen SR (1954) Estimation of available phosphorus in soils by extraction with sodium bicarbonate

Pedroza-Sandoval A, Yáñez-Chávez LG, Sánchez-Cohen I, Samaniego-Gaxiola JA, TrejoCalzada R (2017) Hydrogel, biocompost and its effect on photosynthetic activity and production of forage maize plants (Zea mays L.). Acta Agronómica 66:63-68

Peigné J, Girardin P (2004) Environmental Impacts of Farm-Scale Composting Practices. Water, Air, and Soil Pollution 153:45-68

Putnik-Delić M, Maksimović I, Venezia A, Nagl N (2013) Free proline accumulation in young sugar beet plants and in tissue culture explants under water deficiency as tools for assessment of drought tolerance. Rom Agric Res 30:141-148

Rady MM, Semida WM, Hemida KA, Abdelhamid MT (2016) The effect of compost on growth and yield of Phaseolus vulgaris plants grown under saline soil. International Journal of Recycling of Organic Waste in Agriculture 5:311-321

Reinefield E, Merich AEM, Baumgarten G, Winner C, Besis U (1974) Zur Voraussage des melassezyu cherus aus Ru beanalysen. In: Cooke DA, Scott RK (eds) The sugar beet crop. Chapman and Hall (World Crop Series), London, pp 571-617

Sánchez-Monedero MA, Cayuela ML, Sánchez-García M, Vandecasteele B, D’Hose T, López G, Martínez-Gaitán C, Kuikman PJ, Sinicco T, Mondini C (2019) Agronomic Evaluation of Biochar, Compost and Biochar-Blended Compost across Different Cropping Systems: Perspective from the European Project FERTIPLUS. Agronomy 9:225

Sayara T, Basheer-Salimia R, Hawamde F, Sánchez A (2020) Recycling of Organic Wastes through Composting: Process Performance and Compost Application in Agriculture. Agronomy 10:1838

Shaheen SM, Shams MS, Khalifa MR, El-Dali MA, Rinklebe J (2017) Various soil amendments and environmental wastes affect the (im)mobilization and phytoavailability of potentially toxic elements in a sewage effluent irrigated sandy soil. Ecotoxicology and Environmental Safety $142: 375-387$

Simova-Stoilova L, Vassileva V, Feller U (2016) Selection and Breeding of Suitable Crop Genotypes for Drought and Heat Periods in a Changing Climate: Which Morphological and Physiological Properties Should Be Considered? Agriculture 6:26

Skuras D, Psaltopoulos D (2012) A broad overview of the main problems derived from climate change that will affect agricultural production in the Mediterranean area. Building Resilience for Adaptation to Climate Change in the Agriculture Sector: Proceedings of a Joint FAO/OECD Workshop, pp 217-260

Smith M (1992) CROPWATA computer program for irrigation planning and management 1992. FAO Irrigation and Drainage Publications No. 46 Rome 
440 Smolinska B (2015) Green waste compost as an amendment during induced phytoextraction of

441 mercury-contaminated soil. Environmental Science and Pollution Research 22:3528-3537

442 Tong X, Brandt M, Yue Y, Horion S, Wang K, Keersmaecker WD, Tian F, Schurgers G, Xiao X, 443 Luo Y, Chen C, Myneni R, Shi Z, Chen H, Fensholt R (2018) Increased vegetation growth and 444 carbon stock in China karst via ecological engineering. Nature Sustainability 1:44-50

445 Ullah MR, Corneo PE, Dijkstra FA (2020) Inter-seasonal Nitrogen Loss with Drought Depends 446 on Fertilizer Management in a Seminatural Australian Grassland. Ecosystems 23:1281-1293

447 Vargas-Hernández JG, Pallagst K, Hammer P (2018) Strategic Management Innovation of Urban 448 Green Spaces for Sustainable Community Development. In: Marques J (ed) Handbook of Engaged 449 Sustainability. Springer International Publishing, Cham, pp 1-28

450 Vermeirn L, Gopling GA (1984) Localized irrigation. FAO Irrigation and drainage paper, Rome, 451 Italy

452 Wakeel A (2013) Potassium-sodium interactions in soil and plant under saline-sodic conditions. 453 Journal of Plant Nutrition and Soil Science 176:344-354

454 Zheljazkov VD, Warman PR (2004) Phytoavailability and fractionation of copper, manganese, and 455 zinc in soil following application of two composts to four crops. Environmental Pollution 131:187456195

457

458 
460 Table 1. Effect of the application of green waste-derived compost (GWC) and water deficit on 461 root (RY) and recoverable sugar (RSY) yields under three levels of drip (D) and sprinkler (S) 462 irrigation systems in a sandy soil in 2017/2018 and 2018/2019 growing seasons.

\begin{tabular}{|c|c|c|c|c|c|c|c|c|}
\hline \multirow{2}{*}{ 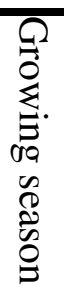 } & \multirow{2}{*}{ 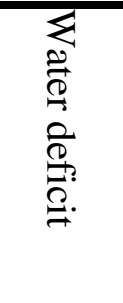 } & \multirow{2}{*}{ 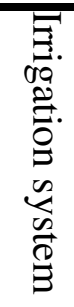 } & \multicolumn{3}{|c|}{$\mathrm{RY}\left(\mathrm{t} \mathrm{ha}^{-1}\right)$} & \multicolumn{3}{|c|}{$\operatorname{RSY}\left(\mathrm{t} \mathrm{ha}^{-1}\right)$} \\
\hline & & & $\stackrel{\Omega}{2}$ & 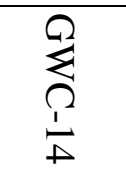 & $\begin{array}{l}\frac{3}{8} \\
\stackrel{8}{0}\end{array}$ & $\stackrel{\Omega}{2}$ & 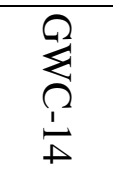 & $\begin{array}{l}\frac{3}{8} \\
\stackrel{8}{3}\end{array}$ \\
\hline \multirow{8}{*}{ 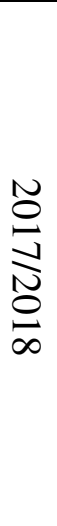 } & \multirow{2}{*}{$60 \%$} & $\mathrm{~S}$ & 47.58 & 49.66 & 48.62 & 8.07 & 8.59 & 8.33 \\
\hline & & $\mathrm{D}$ & 48.33 & 50.55 & 49.44 & 8.25 & 9.04 & 8.65 \\
\hline & \multirow{2}{*}{$80 \%$} & $\mathrm{~S}$ & 53.66 & 58.33 & 56.00 & 8.89 & 9.92 & 9.41 \\
\hline & & $\mathrm{D}$ & 54.98 & 59.35 & 57.17 & 9.35 & 10.33 & 9.84 \\
\hline & \multirow{2}{*}{$100 \%$} & $\mathrm{~S}$ & 55.88 & 59.75 & 57.82 & 9.45 & 10.21 & 9.83 \\
\hline & & $\mathrm{D}$ & 58.67 & 61.35 & 60.01 & 10.09 & 10.77 & 10.43 \\
\hline & \multicolumn{2}{|c|}{ Mean } & 53.18 & 56.50 & 54.84 & 9.02 & 9.81 & 9.42 \\
\hline & \multicolumn{2}{|c|}{$\mathbf{L S D}_{0.05}$} & 2.60 & 2.71 & 2.15 & 0.54 & 0.41 & 0.50 \\
\hline \multirow{8}{*}{$\begin{array}{l}\stackrel{N}{0} \\
\frac{\infty}{N} \\
\stackrel{0}{0} \\
0\end{array}$} & \multirow{2}{*}{$60 \%$} & $S$ & 47.63 & 48.96 & 48.30 & 7.70 & 8.00 & 7.85 \\
\hline & & $\mathrm{D}$ & 48.87 & 51.33 & 50.10 & 8.04 & 8.66 & 8.35 \\
\hline & \multirow{2}{*}{$80 \%$} & $S$ & 52.36 & 54.77 & 53.57 & 8.24 & 8.75 & 8.50 \\
\hline & & $\mathrm{D}$ & 53.74 & 55.67 & 54.71 & 8.86 & 9.35 & 9.11 \\
\hline & \multirow{2}{*}{$100 \%$} & S & 57.98 & 61.22 & 59.60 & 9.29 & 9.92 & 9.61 \\
\hline & & $\mathrm{D}$ & 59.73 & 62.66 & 61.20 & 9.62 & 10.36 & 9.99 \\
\hline & \multicolumn{2}{|c|}{ Mean } & 53.39 & 55.77 & 54.58 & 8.63 & 9.17 & 8.90 \\
\hline & \multicolumn{2}{|c|}{$\mathbf{L S D}_{0.05}$} & 0.38 & 1.89 & 2.30 & 0.63 & 0.46 & 0.51 \\
\hline
\end{tabular}


Table 2. Effect the application of green waste-derived compost (GWC) application and water deficit on quality of the sugar beet variety Gazelle under three levels of drip (D) and sprinkler (S) irrigation systems in a sandy soil in 2017/2018 and 2018/2019 growing seasons.

\begin{tabular}{|c|c|c|c|c|c|c|c|c|c|c|c|c|c|c|}
\hline $\begin{array}{l}Q \\
0 \\
\dot{z}\end{array}$ & $\begin{array}{l}\sum_{0} \\
\stackrel{\overrightarrow{0}}{0}\end{array}$ & $\bar{\Xi}$ & & rose & & & ritie & & & $\mathrm{Z}\left({ }^{\circ}\right.$ & & & $S($ S & \\
\hline 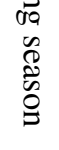 & 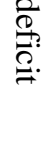 & 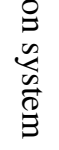 & $\overbrace{0}^{\Omega}$ & $\sum_{1}^{Q}$ & $\begin{array}{l}3 \\
\stackrel{8}{8} \\
\cong\end{array}$ & ? & 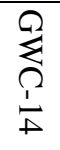 & $\begin{array}{l}3 \\
\stackrel{3}{8} \\
\stackrel{9}{3}\end{array}$ & $\stackrel{8}{2}$ & 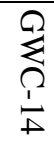 & $\begin{array}{l}3 \\
\stackrel{8}{8} \\
\stackrel{g}{0}\end{array}$ & $\overbrace{0}^{\infty}$ & 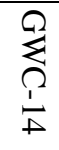 & $\begin{array}{l}3 \\
\stackrel{8}{0}\end{array}$ \\
\hline
\end{tabular}

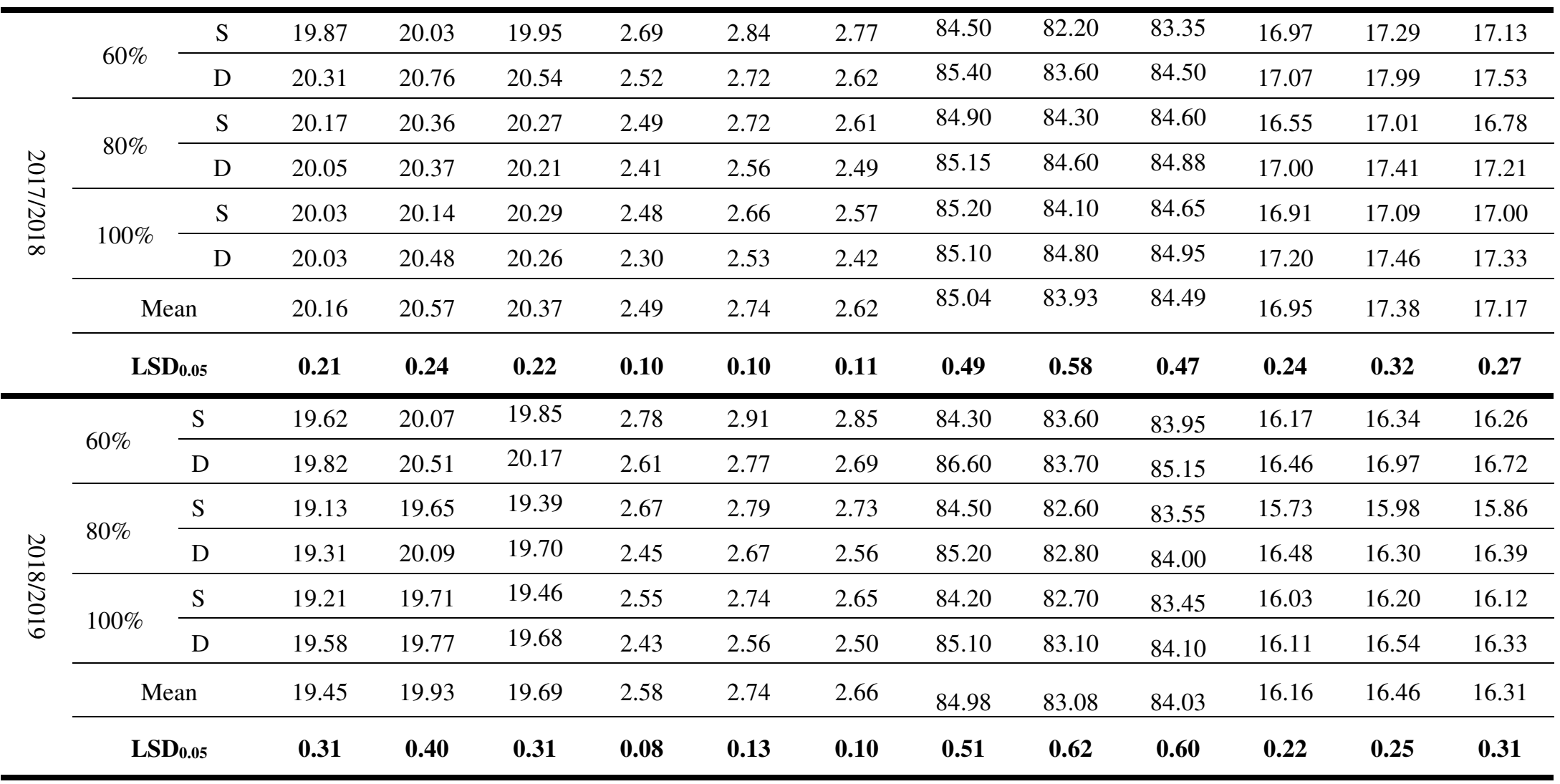


468 Table 3. Effect of green waste-derived compost (GWC) on water use efficiency (WUE) for root 469 yield (RY) and recoverable sugar yield (RSY) of sugar beet under three levels of drip (D) and 470 sprinkler (S) irrigation systems in a sandy soil in 2017/2018 and 2018/2019 growing seasons.

\begin{tabular}{|c|c|c|c|c|c|c|c|c|}
\hline \multirow{2}{*}{$\begin{array}{l}Q \\
0 \\
0 \\
\vdots \\
\vdots \\
0 \\
0 \\
0 \\
0 \\
0 \\
0 \\
0 \\
0\end{array}$} & \multirow{2}{*}{ 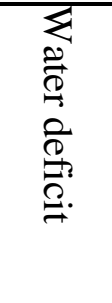 } & \multirow{2}{*}{ 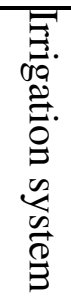 } & \multicolumn{2}{|c|}{$\mathrm{WUE}_{\mathrm{RY}}\left(\mathrm{kg} \mathrm{m}^{-3}\right)$} & \multicolumn{4}{|c|}{ WUERSY $\left(\mathrm{kg} \mathrm{m}^{-3}\right)$} \\
\hline & & & $\overbrace{0}^{\Omega}$ & 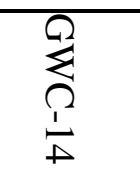 & $\begin{array}{l}\overrightarrow{8} \\
\stackrel{8}{\Xi}\end{array}$ & $\overbrace{0}^{\Omega}$ & 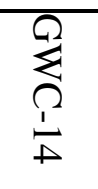 & $\begin{array}{l}3 \\
\stackrel{3}{8}\end{array}$ \\
\hline \multirow{8}{*}{ 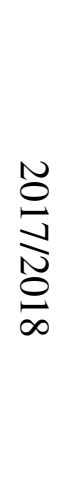 } & \multirow{2}{*}{$60 \%$} & $\mathrm{~S}$ & 9.53 & 9.94 & 9.74 & 1.62 & 1.72 & 1.67 \\
\hline & & $\mathrm{D}$ & 12.16 & 12.72 & 12.44 & 2.08 & 2.27 & 2.18 \\
\hline & \multirow{2}{*}{$80 \%$} & $\mathrm{~S}$ & 8.42 & 9.15 & 8.79 & 1.39 & 1.56 & 1.48 \\
\hline & & $\mathrm{D}$ & 10.82 & 11.68 & 11.25 & 1.84 & 2.03 & 1.94 \\
\hline & \multirow{2}{*}{$\begin{array}{c}100 \\
\%\end{array}$} & $\mathrm{~S}$ & 7.21 & 7.71 & 7.46 & 1.22 & 1.32 & 1.27 \\
\hline & & $\mathrm{D}$ & 9.48 & 9.91 & 9.70 & 1.63 & 1.74 & 1.69 \\
\hline & \multicolumn{2}{|c|}{ Mean } & 9.60 & 10.19 & 9.89 & 1.63 & 1.77 & 1.70 \\
\hline & \multicolumn{2}{|c|}{ LSD0.05 $_{0}$} & 0.19 & 0.18 & 0.19 & 0.06 & 0.09 & 0.08 \\
\hline \multirow{8}{*}{$\begin{array}{l}\stackrel{N}{0} \\
\frac{\infty}{N} \\
\stackrel{0}{0} \\
\sigma\end{array}$} & \multirow{2}{*}{$60 \%$} & $S$ & 9.54 & 9.80 & 9.67 & 1.54 & 1.69 & 1.62 \\
\hline & & $\mathrm{D}$ & 12.29 & 12.91 & 12.60 & 2.02 & 2.18 & 2.10 \\
\hline & \multirow{2}{*}{$80 \%$} & $S$ & 8.22 & 8.59 & 8.41 & 1.29 & 1.38 & 1.34 \\
\hline & & $\mathrm{D}$ & 10.57 & 10.95 & 10.76 & 1.73 & 1.85 & 1.79 \\
\hline & \multirow{2}{*}{$\begin{array}{c}100 \\
\%\end{array}$} & $S$ & 7.48 & 7.90 & 7.69 & 1.20 & 1.29 & 1.25 \\
\hline & & $\mathrm{D}$ & 9.65 & 10.12 & 9.89 & 1.55 & 1.68 & 1.62 \\
\hline & \multicolumn{2}{|c|}{ Mean } & & 9.63 & 10.05 & 9.84 & 1.56 & 1.68 \\
\hline & \multicolumn{2}{|c|}{ LSD0.05 } & 0.24 & 0.24 & 0.20 & 0.22 & 0.08 & 0.11 \\
\hline
\end{tabular}

471

472 


\section{$473 \quad$ Figure legends}

474 Figure 1. Response of recoverable sugar percentages (RS\%) and recoverable sugar yield (RSY) 475 to the root impurities in the beet root juice under the control treatment (A and B: without GWC 476 application) and the application of GWC (C and D) fitted by the linear-linear model over the $477 \quad 2017 / 2018$ and 2018/2019 growing seasons.

478 
A)

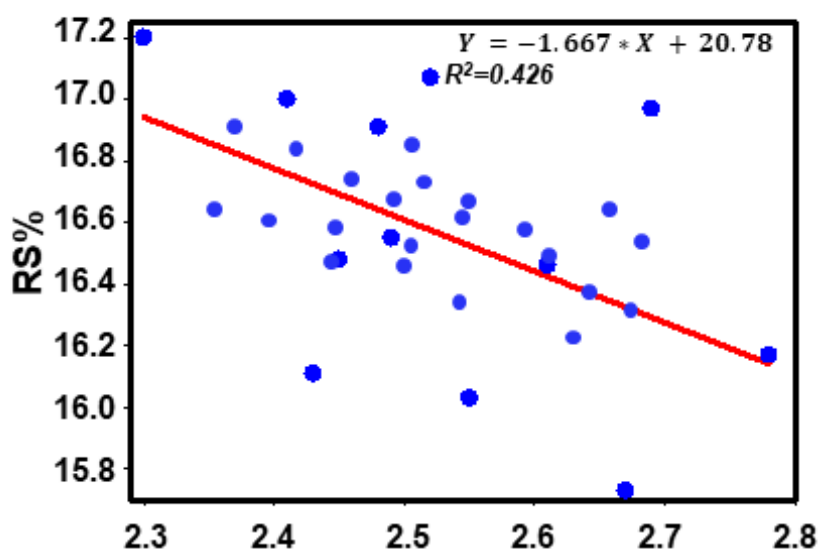

B)

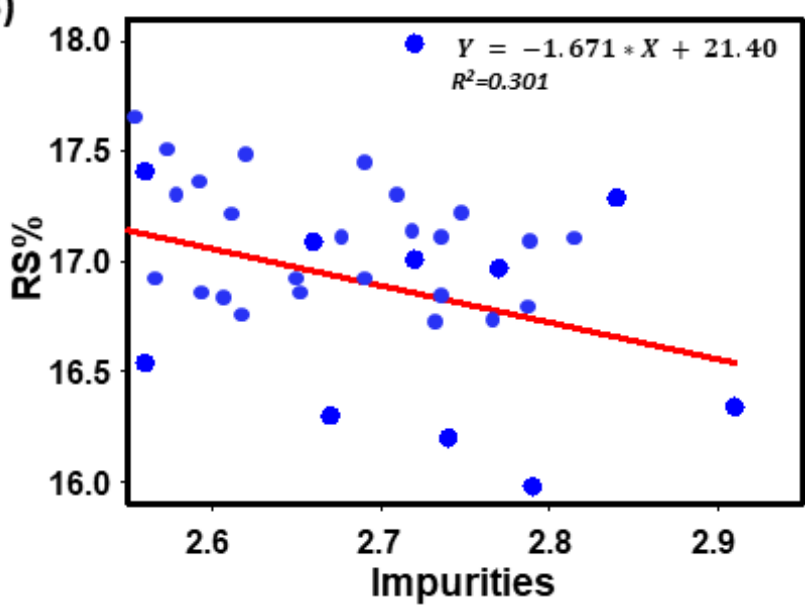

C)
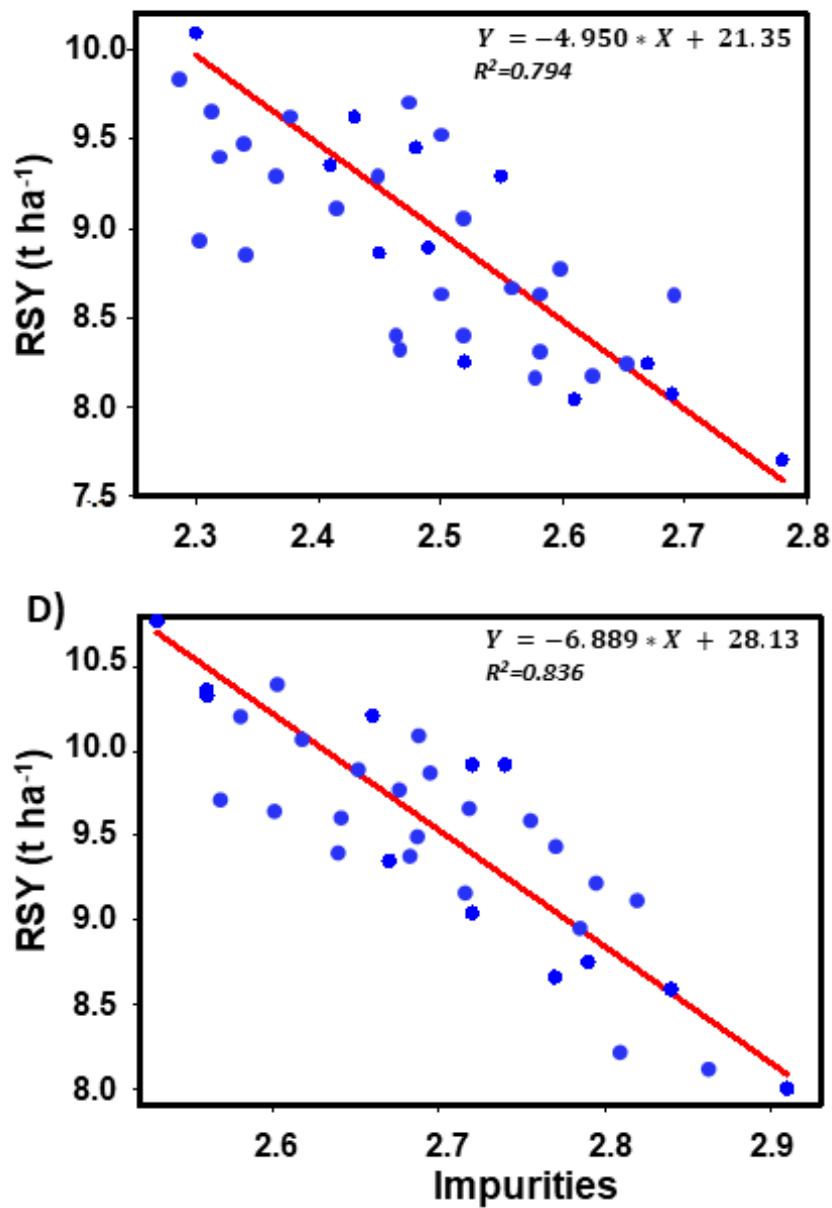

Figure 1

Response of recoverable sugar percentages (RS\%) and recoverable sugar yield (RSY) to the root impurities in the beet root juice under the control treatment (A and B: without GWC application) and the application of GWC (C and D) fitted by the linear-linear model over the 2017/2018 and 2018/2019 growing seasons.

\section{Supplementary Files}

This is a list of supplementary files associated with this preprint. Click to download.

- Suppl.Table1.docx

- Suppl.Table2.docx

- Suppl.Table3.docx 
- Suppl.Table4.docx

- Suppl.Table5.docx 